Japanese Journal of Herpetology 14(2): 79-80., Dec. 1991 (C) 1991 by The Herpetological Society of Japan

\section{A Note on the Reproduction of the Lizard Lacerta vivipara in Hokkaido, Japan}

\author{
SEN TAKENAKA
}

\begin{abstract}
A female of Lacerta vivipara from Hokkaido laid five baby lizards enclosed in transparent membranes on 8 July 1989. The mean snout-vent length of the hatchlings was $22 \mathrm{~mm}$, and the mean mass was $0.20 \mathrm{~g}$. This was the first confirmation of the viviparity of $\boldsymbol{L}$. vivipara from Hokkaido, Japan.
\end{abstract}

Key words: Lacerta vivipara; reproduction; viviparity; Hokkaido; Japan

A female of the lizard Lacerta vivipara was captured at Toyotomi-cho, Teshio-gun, Hokkaido $\left(45^{\circ} 10^{\prime} \mathrm{N}\right)$ on 22 June, 1989. She was gravid then, and was $62 \mathrm{~mm}$ snout-vent length (SVL) and $4.85 \mathrm{~g}$ body mass. Her tail was broken at the time of capture, and the remaining base was $26 \mathrm{~mm}$. She was reared in a terrarium lit intermittently with a lamp and fed with mealworms, crickets and other arthropods.

She laid five baby lizards enclosed in transparent membranes on 8 July 1989 . They were found in moistened dead bog moss placed on the floor at $1610 \mathrm{~h}$ (Fig. 1). The nose of a baby lizard protruded from the membrane then. Membranes of eggs were stuck together. At $1715 \mathrm{~h}$ the heads of four baby lizards and the tail of one baby appeared. The four baby lizards appearing headfirst successfully got out of the membranes by $1745 \mathrm{~h}$ (Fig. 1). The one coming out tail first, failed to slip out of the membrane and died in it.

The mother lizard was $62 \mathrm{~mm}$ SVL and $3.89 \mathrm{~g}$ just after the laying. Her tail was $43 \mathrm{~mm}$, and the regenerated part was $14 \mathrm{~mm}$. Measurements of the baby lizards are shown in Table 1. The total mass of the hatchlings was $0.99 \mathrm{~g}$, and the total mass of the remaining membranes, yolk sacs, etc. was $0.34 \mathrm{~g}$.

The ratio of average hatchling mass to postoviposition mother mass was $5.1 \%$, which was lower than in other Japanese oviparous lacertids (6.5-13.3\%; Takenaka, 1989). The ratio of total mass of hatchlings to post-oviposition mother was $25.4 \%$, which was average for other Japanese oviparous lacertid lizards (Takenaka, 1989). Neonate size was somewhat larger than that reported for a British population (1722 mm SVL; Smith, 1973), and clutch size was smaller than those of Britain, where most clutches were six or more (Avery, 1975). The season and manner of this breeding accorded with the normal reproduction of the viviparous populations of L. vivipara in France (Panigel, 1956). In Sakhalin, north of Hokkaido, a parturition was observed in August; the clutch size was five, the babies' SVL, $20 \mathrm{~mm}$, and the tail length, $20 \mathrm{~mm}$ (Yoshikura, 1938). For these comparisons, of course, more data are needed.

In most of the distribution range, from the Massif Central (France) to Sakhalin, the reproductive mode of $L$. vivipara is viviparous, and oviparous populations have been reported from the Pyrenees and Aquitaine, Spain and France (e.g., Heulin, 1990; Heulin and Guillaume, 1989; Inukai, 1927). This report is
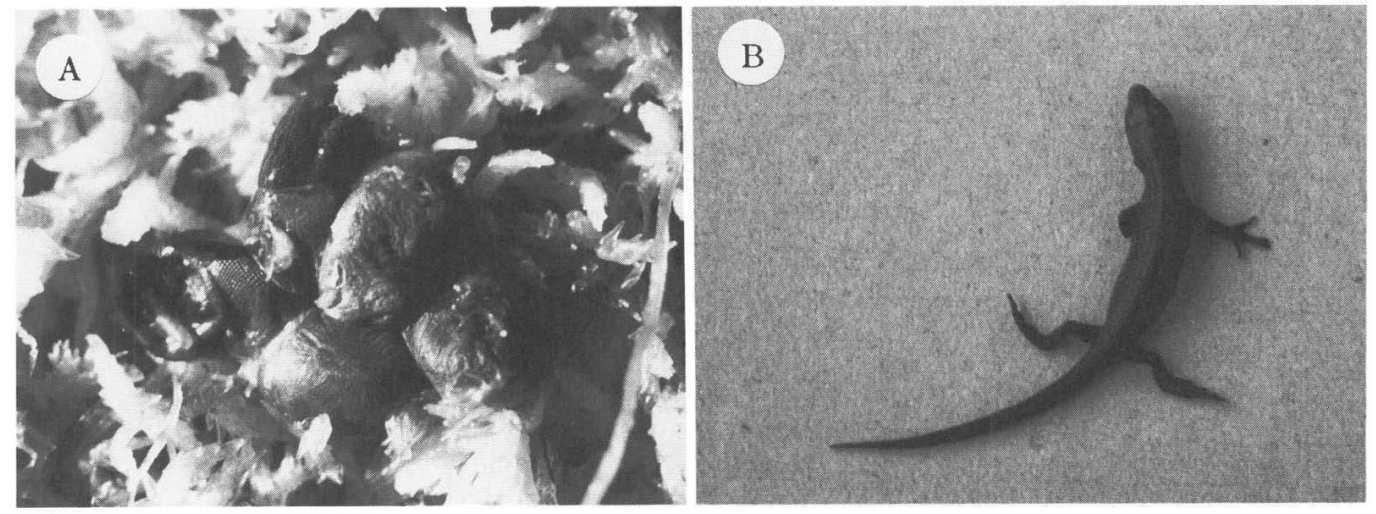

FIG. 1. Baby lizards of Lacerta vivipara; (A) lizards enclosed in transparent membranes and (B) a lizard just after getting out of the membrane. 
TABLE 1. Body size and mass of Lacerta vivipara hatchlings.

\begin{tabular}{ccccc}
\hline $\begin{array}{c}\text { Individual } \\
\text { number }\end{array}$ & Condition & $\begin{array}{c}\text { SVL } \\
(\mathrm{mm})\end{array}$ & $\begin{array}{c}\text { Tail length } \\
(\mathrm{mm})\end{array}$ & $\begin{array}{c}\text { Body mass } \\
(\mathrm{g})\end{array}$ \\
\hline 1 & live & 21 & 22 & 0.190 \\
2 & live & 21 & 21 & 0.166 \\
3 & live & 23 & 23 & 0.213 \\
4 & live & 22 & 22 & 0.187 \\
5 & dead & 22 & 22 & 0.236 \\
\hline
\end{tabular}

the first confirmation of viviparity of Japanese $L$. vivipara since the species was found in the northern part of Hokkaido in 1961 (Inukai et al., 1972). The range of viviparous populations should be revised to a wider one.

\section{Literature Cited}

Avery, R. A. 1975. Clutch size and reproductive effort in the lizard Lacerta vivipara Jacquin. Oecologia 19: 165-170.

Heulin, B. 1990. Étude comparative de la membrane coquillère chez les souches ovipare et vivipare du lézard Lacerta vivipara. Can. J. Zool. 68: 10151019.

Heulin, B. and C. Guillaume. 1989. Extension géographique des populations ovipares de Lacerta vivipara. Rev. Ecol. Terre Vie 44: 39-45.

INUKAI, T. 1927. Beiträge zur Entwicklungsgeschichte der Reptilien. 1. Die frühesten Entwicklungsvorgänge bei der Waldeidechse, Lacerta vivipara Jacq. J. Coll. Agr. Hokkaido Imp. Univ. 16: 125-201.

\section{要旨 北海道産コモチカナヘビの生殖の記録}

竹中 践

北海道のコモチカナへビの胎生が確認された. 1989年 6 月22日に北海道・豊富町に执いて捕獲 されたコモチカナへビの雌が，飼育下で同年 7 月 8 日に 5 個体の仔を産んだ。透明な膜につつ まれて産み落とされた仔は，その日の内に膜か
INUKaI, T., Y. Ota, H. Abe and T. Kobayashi. 1972. Terrestrial vertebrates. In: Inukai, T. (ed.), Reports of Scientific Research on Sarobetsu 7. p. 318. Hokkaido Kaihatsu-kyoku. (in Japanese)

Panigel, M. 1956. Contribution à l'étude de l'ovoviviparité chez les reptiles: gestation et parturition chez le lézard vivipare Zootoca vivipara. Ann. Sci. Nat., Zool. 11: 569-668.

Smith, M. 1973. The British Amphibians and Reptiles. 5 th ed. 322 p. Collins, London.

TAKENAKA, S. 1989. Reproductive ecology of Japanese lacertid lizards. In: M. Matsui, T. Hikida and R. C. Gorris (eds.), Current Herpetology in East Asia. p. 364-369. Herpetol. Soc. Jpn., Kyoto.

YoshikURA, M. 1938. Observations on the breeding habits of Lacerta vivipara Jaquin. Shokubutsu oyobi Dobutsu (Botany and Zoology) 6: 823-826. (in Japanese)

Department of Natural Sciences, Hokkaido Tokai University, Minamisawa, Minami-ku, Sapporo, 005 JAPAN

ら脱出した。仔の平均体長は $22 \mathrm{~mm}$, 平均体 重は $0.20 \mathrm{~g}$ であった。

（005 北海道札幌市南区南沢 5 条 北海道東 海大学教育開発研究センター) 